\title{
PENGARUH PEMBELAJARAN DENGAN METODE DEMONTRASI TERHADAP KEMAMPUAN BERPIKIR KREATIF DAN KONEKSI MATEMATIK SERTA MOTIVASI BELAJAR SISWA SMP
}

\author{
Turiman \\ Sekolah Menengah Pertama Negeri 5 Cikalongkulon \\ galuhturiman01@gmail.com
}

\begin{tabular}{l|l} 
Penerimaan : 17 Januari 2018 & Diterima: 30 Desember 2018
\end{tabular}

\begin{abstract}
ABSTRAK
Hasil belajar matematika sampai saat ini masih tergolong rendah, hal ini terjadi karena guru dalam menyampaikan materi pelajaran hanya mengejar untuk target bisa mengerjakan ujian dan juga guru dalam menyampaikan pembelajaran memilih metode yang monoton, solusi salah satu metode pembelajaran adalah metode demontrasi dengan metode tersebut siswa bisa langsung praktek menggunakan alat peraga untuk mempermudah cara belajar. Untuk mengembangkan kemampuan siswa dalam belajar matematika diantaranya adalah kemampuan berpikir kreatif dan koneksi matematik karena kedua kemampuan tersebut mampu mendorong siswa untuk aktif dalam proses pembelajaran, melalui pembelajaran dengan pendekatan Metode Demontrasi kemampuan berpikir kreatif dan koneksi siswa lebih baik dari pada siswa yang pembelajarannya dengan konvensional. Kesulitan yang dialami siswa adalah waktu yang tidak cukup, mengubah soal cerita ke dalam model matematika.
\end{abstract}

Kata Kunci: Berpikir Kreatif, Koneksi Matematik, Metode Demontrasi

\section{PENDAHULUAN}

Banyak keluhan dalam masyarakat tentang pendidikan di Indonesia khususnya mata pelajaran matematika yang masih menjadi beban dan menakutkan oleh para siswa di sekolah. Proses pendidikan yang berlangsung saat ini dipersiapkan sekedar untuk menghadapai soal - soal ujian, akibatnya pelaksanaan proses belajar mengajar hanya terbatas pada upaya guru memberikan seperangkat pengetahuan yang ada hubungannya dengan soal - soal ujian.

Rahmawati (Sabandar, 2010), menyatakan bahwa berpikir kreatif sesungguhnya adalah suatu kemampuan berpikir yang berawal dari adanya kepekaan terhadap situasi yang sedang dihadapi, bahwa situasi itu terlihat atau teridentifikasi adanya masalah yang ingin harus diselesaikan.

Menurut Sumarmo (2014), menyatakan bahwa koneksi matematik merupakan kemampuan dasar mengaplilkasikan konsep matematika dalam penyelesaian masalah nyata. Dalam belajar matematik siswa hendaknya memahami koneksi antar ide-ide matematik, dan antar matematik dengan bidang studi lainnya 
Santrock (Sardiman, 2010), mengatakan motivasi adalah proses yang memberi semangat, arah, dan kegigihan perilaku. Artinya, perilaku yang memiliki motivasi adalah perilaku yang penuh energi, terarah, dan bertahan lama. Dalam kegiatan belajar, maka motivasi dapat dikatakan sebagai keseluruhan daya penggerak di dalam diri siswa yang menimbulkan kegiatan belajar, yang menjamin kelangsungan dari kegiatan belajar dan memberikan arah pada kegiatan belajar, sehingga tujuan yang dikehendaki oleh subjek belajar itu dapat tercapai.

\section{METODOLOGI PENELITIAN}

Metode penelitian ini adalah kuasi eksperimen, yaitu jenis penelitian yang menyertakan kelompok eksperimen dan kelompok kontrol. Kelas eksperimen mendapat pembelajaran dengan menggunakan pendekatan metode demonstrasi, sedangkan kelas kontrol diberikan pembelajaran dengan pendekatan pembelajaran biasa. Sebelum penelitian kelas eksperimen dan kelas kontrol diberikan pretes untuk mengetahui kemampuan awal siswa. Kemudian kedua kelas di berikan pembelajaran yang berbeda yaitu kelas eksperimen dengan pendekatan metode demontrasi sedangkan kelas kontrol dengan pendekatan konvensional. Desain penelitian dapat digambarkan sebagai berikut :

$\begin{array}{ccc}O \quad X & O \\ -O & & 0\end{array}$

Keterangan :

$\mathrm{O}:$ Pretes $=$ Postes kemampuan berpikir kreatif dan koneksi matematik

$\mathrm{X}$ : Pembelajaran dengan pendekatan metode demontrasi

------- : Pengambilan sampel tidak acak

\section{HASIL DAN PEMBAHASAN}

\section{Kemampuan Berpikir Kreatif}

Sebelum melakukan penelitian dilakukan uji pretes terlebih dahulu untuk mengetahui kemampuan awal siswa pada kedua kelompok yang akan diteliti, data skor pretes dianalisis dengan bantuan Softwere SPSS 20.0 for windows, berikut ini adalah output dari data skor pretes. Berikut adalah output dari data pretes. 


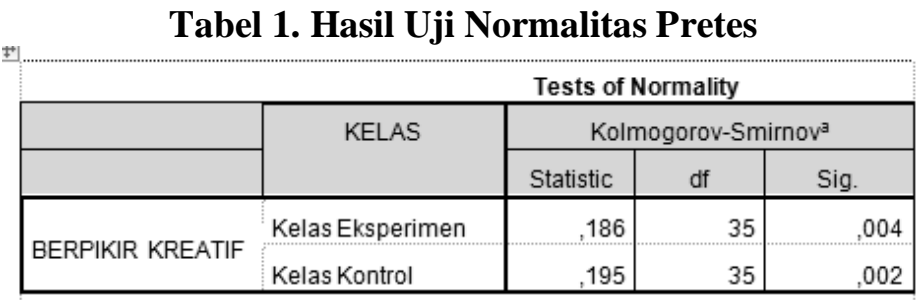

Diambil dari output SPSS 17

Pada tabel 1 hasil uji normalitas nilai sig adalah 0,004 karena nilai sig 0,004 $<0,05$ maka sampel data berasal dari populasi tidak berdistribusi normal, maka selanjutnya akan dilakukan uji Mann-Whitney yang hasilnya disajikan dalam tael 2 berikut.

Tabel 2. Hasil Uji Mann-Whitney

\begin{tabular}{|l|r|}
\hline \multicolumn{2}{|c|}{ Test Statistics $^{\mathbf{a}}$} \\
\hline Mann-WhitneyU & \multicolumn{1}{|c|}{ BERPIKIR KREATIF } \\
\hline Wilcoxon W & 595,500 \\
$Z$ & 1225,500 \\
Asymp. Sig. (2-tailed) &,- 207 \\
\hline Diambil dari output SPSS 20 &, 836 \\
\hline
\end{tabular}

Pada tabel 2 hasil uji Mann-Whitney nilai Asymp.Sig.(2-tailed) adalah 0,836 karena nilai sig 0,836 > 0,05 maka dapat disimpulkan tidak terdapat perbedaan yang signifikan antara siswa pembelajarannya akan menggunakan pendekatan metode demontrasi dengan siswa yang akan menggunakan pendekatan pembelajaran biasa.

Setelah selesai pretes dilanjutkan kegiatan pembelajaran seperti yang telah direncanakan data skor hasil penelitian postes semuanya dianalisis dengan bantuan Softwere SPSS 20.0 for windows, berikut ini adalah output dari data penelitian.

Tabel 3. Hasil Uji Normalitas Kemampuan Berpikir Kreatif

\begin{tabular}{|c|c|c|c|c|}
\hline \multicolumn{5}{|c|}{ Tests of Normality } \\
\hline & \multirow[t]{2}{*}{ Berpikir Kreatif } & \multicolumn{3}{|c|}{ Kolmogorov-Smirnov ${ }^{3}$} \\
\hline & & Statistic & df & Sig. \\
\hline \multirow[t]{2}{*}{ Berpikir Kreatif } & $\begin{array}{l}\text { Kelas } \\
\text { Eksperimen }\end{array}$ & , 197 & 35 &, 001 \\
\hline & Kelas Kontrol & ,123 & 35 & $200^{-}$ \\
\hline
\end{tabular}


Pada tabel 3 hasil pengujian pada Kolmogorov-Smirnov dengan kriteria 0,05 menunjukan hasil bahwa nilai Sig pada kelas eksperimen adalah 0,001, karena nilai sig adalah $0,001<0,05$ artinya sampel data berasal dari populasi yang tidak berdistribusi normal maka akan dilanjutkan ke uji Mann - Whitney, adapun hasilnya disajikan dalam pada tabel 4 .

Tabel 4. Hasil Uji Mann-Whiney Kemampuan Berpikir Kreatif

\begin{tabular}{|l|r|}
\hline \multicolumn{2}{|c|}{ Test Statistics $^{\mathrm{a}}$} \\
\hline Mann-Whitney U & \multicolumn{1}{|c|}{ BERPIKIR KREATIF } \\
\hline Wilcoxon W & 356,500 \\
Z & 986,500 \\
Asymp. Sig. (2-tailed) & $-3,018$ \\
\hline Diambil daru Output SPSS 20 &, 003 \\
\hline
\end{tabular}

Pada tabel 4 hasil pengujian bahwa nilai pada Asymp.Sig.(2-tailed) adalah 0,003, karena nilai sig 0,003 < 0,05 maka dapat disimpulkan bahwa pencapaian hasil belajar matematika siswa dengan pendekatan Metoda Demontrasi lebih baik dari siswa yang mendapat pembelajaran biasa. Untuk mengetahui apakah terjadi peningkatan hasil belajar maka dilakukan uji gain. Gain dilakukan untuk mengatahui peningkatan kemampuan berpikir siswa. Berikut ini hasil uji normalitas gain disajikan dalam tabel 5.

Tabel 5 Hasil Uji Normalitas Gain Kemampuan Berpikir kreatif

\begin{tabular}{|c|c|c|c|c|}
\hline \multicolumn{5}{|c|}{ Tests of Normality } \\
\hline & \multirow[t]{2}{*}{ GAIN } & \multicolumn{3}{|c|}{ Kolmogorov-Smirnov ${ }^{3}$} \\
\hline & & Statistic & df & Sig. \\
\hline \multirow{3}{*}{ GAIN } & Kelas & & & \\
\hline & Eksperimen & , & 3 &, 004 \\
\hline & Kelas Kontrol & 147 & 35 & ,055 \\
\hline
\end{tabular}

Pada tabel 5 hasil pengujian bahwa nilai sig adalah 0,004 karena nilai sig 0,004< 0,05 artinnya sampel data berasal dari populasi yang tidak berdistribusi normal, maka dilanjutkan ke uji Mann-Whitney. Hasil uji Mann-Whitney disajikan dalam tabel 6 berikut.

Tabel 6 Hasil Uji Mann-Whitney Gain Kemampuan Berpikir Kreatif

\begin{tabular}{|l|r|}
\hline \multicolumn{2}{|c|}{ Test Statistics $^{{ }^{2}}$} \\
\hline Mann-Whitney U & GAIN \\
\hline Wilcoxon W & 354,000 \\
Z & 984,000 \\
\hline Asymp. Sig. (2-tailed) & $-3,039$ \\
\hline a. Grouping Variable: GAIN &, 002 \\
\hline
\end{tabular}


Pada tabel 6 hasil Pengujian bahwa nilai pada Asymp. Sig.(2-tailed) adalah 0,002, karena nilai sig 0,002 <0,05, dapat disimpulkan bahwa terdapat penigkatan hasil belajar siswa yang signifikan pada pembelajaran dengan menggunakan pendekatan Metode Demontrasi.

\section{Kemampuan Koneksi Matematik}

Untuk mengetahui apakah data pada pretes berdistribusi normal dilakukan uji normalitas terlebih dahulu, hasil uji normalitas disajikan dalam tabel 7 berikut.

Tabel 7. Hasil Uji Normalitas Pretes

\begin{tabular}{|l|l|r|r|r|}
\hline \multicolumn{5}{|c|}{ Tests of Normality } \\
\hline & KONEKSI MATEMATIK & \multicolumn{3}{|c|}{ Kolmogorov-Smirnov } \\
\cline { 3 - 5 } & & \multicolumn{1}{c|}{ Statistic } & \multicolumn{1}{c|}{ Df } & \multicolumn{1}{c|}{ Sig. } \\
\hline KONEKSI & Kelas Eksperimen &, 237 & 35 &, 000 \\
MATEMATIK & Kelas Kontrol &, 202 & 35 &, 001 \\
\hline \multicolumn{2}{|l|}{ Diambil dari output SPSS 20 }
\end{tabular}

Pada tabel 7 hasil uji normalitas bahwa nilai sig adalah 0,000 karena nilai sig 0,000 $<0,05$ maka sampel data berasal dari popilasi tidak berdistribusi normal, maka akan dilanjukan ke uji Mann-Whitney yang hasilnya disajikan dalam tabel 8 berikut

Tabel 8 Hasil Uji Mann-Whitney

\begin{tabular}{|l|r|}
\hline \multicolumn{2}{|c|}{ Test Statistics $^{\text {a }}$} \\
\hline & KONEKSI MATEMATIK $^{|c|}$ \\
\hline Mann-Whitney U & 548,000 \\
Wilcoxon W & 1178,000 \\
$Z$ & -789 \\
Asymp. Sig. (2-tailed) &, 430 \\
\hline \multicolumn{2}{|l}{ Diambil dari output SPSS 20} \\
\hline
\end{tabular}

Pada tabel 8 hasil uji Mann-Whitney pada Asymp.Sig.(2-tailed) adalah 0,430 karena nilai sig 0,430>0,05 maka dapat disimpulkan bahwa tidak terdapat perbedaan signifikan antara siswa yang pembelajarannya akan menggunakan pendekatan metode demontrasi dengan siswa yang akan menggunakan pembelajaran biasa. 
Setelah uji pretes selanjutnya dilakukan pembelajaran seperti yang telah direncanakan, untuk mengetahui apakah populasi berasal dari data berdistribusi normal maka dilakukan uji normalitas, hasil uji normalitas disajikan dalam tabel 9 berikut ini.

Tabel 9. Hasil Uji Normalitas Kemampuan Koneksi Matematik

\begin{tabular}{|l|l|r|r|r|}
\hline \multicolumn{1}{|c|}{ Tests of Normality } \\
\hline & KONEKSI & \multicolumn{3}{|c|}{ Kolmogorov-Smirnov } \\
\cline { 3 - 6 } & MATEMATIK & Statistic & \multicolumn{1}{c|}{ df } & \multicolumn{1}{c|}{ Sig. } \\
\hline \multirow{2}{*}{ KONEKSI MATEMATIK Kelas Eksperimen } & 126 & 35 &, 174 \\
& Kelas Kontrol &, 100 & 35 &, $200^{\circ}$ \\
\hline
\end{tabular}

Pada tabel 9 hasil hasil pengujian bahwa sig adalah 0,174 karena nilai sig 0,174 > 0,05 artinya sampel data berasal dari populasi berdistribusi normal, maka akan dilanjutkan ke uji homogenitas, hasil uji homogenitas disajikan dalam tabel 10 berikut ini.

Tabel 10. Hasil Uji Homogenitas Kemampuan Koneksi Matematik

\begin{tabular}{|c|c|c|c|c|c|}
\hline \multicolumn{6}{|c|}{ Test of Homogeneity of Variance } \\
\hline & & $\begin{array}{l}\text { Levene } \\
\text { Statistic }\end{array}$ & df1 & df2 & Sig. \\
\hline \multirow{4}{*}{$\begin{array}{l}\text { KONEKSI } \\
\text { MATEMATIK }\end{array}$} & Based on Mean & 10,019 & 1 & 68 &, 002 \\
\hline & Based on Median & 10,127 & 1 & 68 & 002 \\
\hline & $\begin{array}{l}\text { Based on Median and with } \\
\text { adjusted df }\end{array}$ & 10,127 & 1 & 58,536 &, 002 \\
\hline & Based on trimmed mean & 10,252 & 1 & 68 &, 002 \\
\hline
\end{tabular}

Pada tabel 10 hasil uji homogenitas bahwa nilai sig adalah 0,002 karena nilai sig $0,002<0,05$ artinya variansi data tidak homogen, maka akan dilanjtkan ke Uji-t', hasil Ujit' disajikan dalam tabel 11 berikut ini.

Tabel 11. Hasil Uji-t' Kemampuan koneksi Matematik

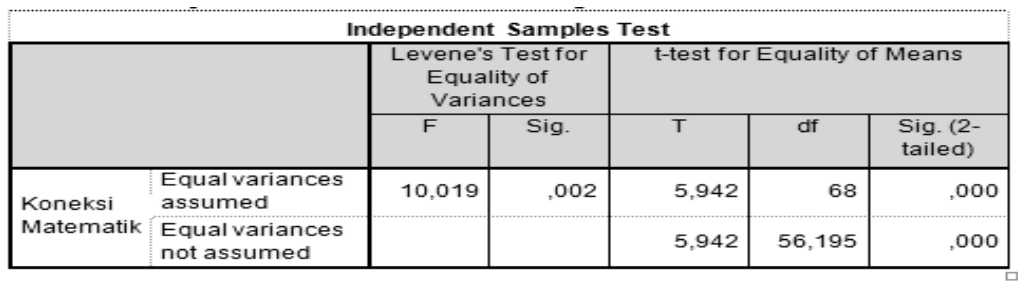

Diambil dari output SPSS 20

Pada tabel 11 hasil uji-t' bahwa nilai sig adalah 0,000, karena dilakukan uji satu pihak maka nilai sig : 2 jadi $0,000: 2=0$, karena $0,000<0,05$, maka dapat disimpulkan bahwa pencapaian kemampuan koneksi matematik siswa yang pembelajarannya dengan pendekatan metode demontrasi lebih baik dari pada siswa dengan pembelajaran biasa. Untuk mengetahui apakah terjadi peningkatan hasil belajar maka dilakukan uji gain. Gain 
dilakukan untuk mengatahui peningkatan kemampuan berpikir siswa. Berikut ini hasil uji normalitas gain disajikan dalam tabel 12 .

Tabel 12. Hasil Uji Normalitas Gain Kemampuan Koneksi Matematik

\begin{tabular}{|l|l|r|r|r|}
\hline \multicolumn{6}{|c|}{ Tests of Normality } \\
\hline \multirow{2}{*}{} & \multirow{2}{*}{ GAIN } & \multicolumn{3}{|c|}{ Kolmogorov-Smirnov } \\
\cline { 3 - 6 } & & \multicolumn{1}{|c|}{ Statistic } & \multicolumn{1}{c|}{ df } & \multicolumn{1}{c|}{ Sig. } \\
\hline \multirow{2}{*}{ GAIN } & Kelas Eksperimen & .217 & 35 &, 000 \\
& Kelas Kontrol &, 103 & 35 &, $200^{\circ}$ \\
\hline
\end{tabular}

Pada tabel 12 hasil uji normalitas bahwa nilai sig adalah 0,000 karena nilai sig $0,000<0,05$ artinya bahwa sampel data berasal dari populasi yang tidak berdistribusi normal, maka akan dilanjutkan ke uji Mann-Whitney yang disajikan dalam tabel 13 berikut ini.

Tabel 13. Hasil Uji mann-Whitney Gain Kemampuan Koneksi Matematik

\begin{tabular}{|l|r|}
\hline \multicolumn{2}{|c|}{ Test Statistics $^{\mathrm{a}}$} \\
\hline & \multicolumn{2}{|c|}{ GAIN } \\
\hline Mann-WhitneyU & 394,500 \\
Wilcoxon W & 1024,500 \\
$Z$ & $-2,563$ \\
\hline Asymp. Sig. (2-tailed) &, 001 \\
\hline \multicolumn{2}{|l|}{ Diambil dari output SPSS 20 } \\
\hline
\end{tabular}

Pada tabel 13, hasil uji Mann-Whitney bahwa nilai pada Asymp.sig.(2-tailed) adalah 0,001 karena nilai sig 0,001 $<0,05$ artinya bahwa terjadi peningkatan yang signifikan pada siswa yang mendapat pembelajaran dengan pendekatan metode demontrasi.

\section{Motivasi Belajar Siswa}

Untuk mengetahui apakah sampel data berdistribusi normal atau tidak, dilakukan uji normalitas, hasil uji normalitas disajikan dalam tabel 14 beriukt ini.

Tabel 14 Hasil Uji Normalitas Skala Motivasi Belajar Siswa

\begin{tabular}{|l|l|r|r|r|}
\hline \multicolumn{5}{|c|}{ Tests of Normality } \\
\hline & MOTIVASI & \multicolumn{3}{|c|}{ Kolmogorov-Smirnov } \\
\cline { 3 - 6 } & BELAJAR & Statistic & \multicolumn{1}{c|}{ Df } & \multicolumn{1}{c|}{ Sig. } \\
\hline & Kelas Eksperimen &, 129 & 35 &, 154 \\
\hline MOTIASI & Kelas Kontrol &, 139 & 35 &, 086 \\
\hline BELAJAR & Kiambil dari SPSS 20
\end{tabular}


Pada tabel 14 hasil uji normalitas bahwa nilai sig adalah 0,154 karena nilai sig $0,154>0,05$ artinya sampel data berasal populasi yang berdistribusi normal, maka akan dilanjutkan ke uji homogenitas, hasil uji homogenitas disajikan dalam tabel 15 berikutini.

Tabel 15. Hasil Uji Homogenitas Skala Motivasi Belajar Siswa

\begin{tabular}{|c|c|c|c|c|c|}
\hline \multicolumn{6}{|c|}{ Test of Homogeneity of Variance } \\
\hline & & $\begin{array}{l}\text { Levene } \\
\text { Statistic }\end{array}$ & df1 & df2 & Sig. \\
\hline \multirow{4}{*}{$\begin{array}{l}\text { MOTIASI } \\
\text { BELAJAR }\end{array}$} & Based on Mean &, 423 & 1 & 68 & 518 \\
\hline & Based on Median &, 463 & 1 & 68 & 499 \\
\hline & $\begin{array}{l}\text { Based on Median and with } \\
\text { adjusted df }\end{array}$ & 463 & 1 & 61,810 &, 499 \\
\hline & Based on trimmed mean & .462 & 1 & 68 & ,499 \\
\hline
\end{tabular}

Pada tabel 15 hasil uji homogenitas adalah 0,518 karena nilai sig 0,518 > 0,05 artinya sampel data adalah memiliki varian homogen, maka akan dilanjutkan ke uji-t, hasil uji-t disajikan dalam tabel 13 berikut ini.

Tabel 16. Hasil uji-t Skala Motivasi Belajar Siswa

\begin{tabular}{|c|c|c|c|c|c|c|}
\hline \multicolumn{7}{|c|}{ Independent Samples Test } \\
\hline & & \multicolumn{2}{|c|}{$\begin{array}{l}\text { Levene's Test for } \\
\text { Equality of Variances }\end{array}$} & \multicolumn{3}{|c|}{ t-test for Equality of Means } \\
\hline & & $\mathrm{F}$ & Sig. & $t$ & df & $\begin{array}{l}\text { Sig. (2- } \\
\text { tailed) }\end{array}$ \\
\hline \multirow{2}{*}{$\begin{array}{l}\text { MOTIASI } \\
\text { BELAJAR }\end{array}$} & $\begin{array}{l}\text { Equal variances } \\
\text { assumed }\end{array}$ & ,423 &, 518 & 4,988 & 68 &, 000 \\
\hline & $\begin{array}{l}\text { Equal variances } \\
\text { not assumed }\end{array}$ & & & 4,988 & 67,934 &, 000 \\
\hline
\end{tabular}

Diambil dari output SPSS 20

Pada tabel 16 hasil uji-t adalah 0,000 karena nilai sig 0,000 <0,005 artinya bahwa motivasi belajar siswa yang mendapat pembelajaran dengan pendekatan metode demontrasi lebih baik dari pada siswa yang mendapat pembelajaran biasa.

\section{Asosiasi Setiap Kemampuan}

\section{a. Asosiasi Kemampuan Berpikir Kreatif dengan Koneksi Matematik.}

Asosiasi berguna untuk mengetahui apakah ada kaitan antara kemampuan berpikir kreatif dengan koneksi Matematik, berpikir kreatif dengan skala motivasi, kemampuan koneksi matematik dengan skala motivasi, selanjutnya akan melakukan uji Chi-Square yang hasilnya disajikan dalam tabel 17 berikut.

Tabel 17 Hasil Chi Square kemampuan Berpikir Kreatif dengan Koneksi Matematik 


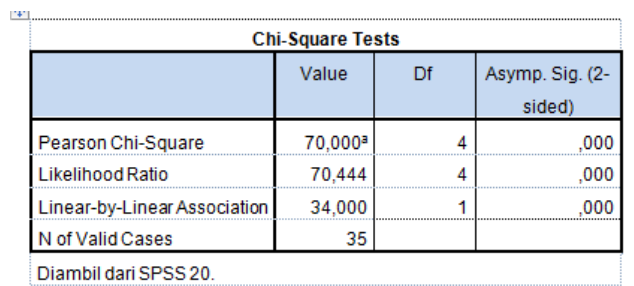

Pada tabel 17 hasil uji Chi-Square bahwa sig adalah 0,043 karena nilai sig 0,043< 0,05 artinya terdapat asosiasi antara kemampuan berpikir kreatif dengan koneksi matematik, selanjutnya akan dilakukan uji kontingensi $\mathrm{C}$, hasinya disajikan dalam tabel 18 berikut.

\section{Tabel 18 Hasil Uji Kontingensi C}

\begin{tabular}{|c|c|c|c|c|c|}
\hline \multicolumn{6}{|c|}{ Symmetric Measures } \\
\hline & & Value & $\begin{array}{l}\text { Asymp. Std. } \\
\text { Error }\end{array}$ & Approx. To & Approx. Sig. \\
\hline $\begin{array}{l}\text { Nominal by } \\
\text { Nominal }\end{array}$ & $\begin{array}{l}\text { Contingency } \\
\text { Coefficient }\end{array}$ & ,390 & & & ,043 \\
\hline Ordinal by & Gamma & -286 & .303 & -873 & .382 \\
\hline Ordinal & Spearman Correlation & -150 & .172 & -874 & $.388^{\circ}$ \\
\hline $\begin{array}{l}\text { Interval by } \\
\text { Interval }\end{array}$ & Pearson's R &,- 087 & , 166 & - -504 & $617^{\circ}$ \\
\hline \multicolumn{2}{|c|}{ Nof ValidCases } & 35 & & & \\
\hline
\end{tabular}

Hasil uji kontingensi $\mathrm{C}$ pada Value adalah 0,816,selanjutnya hitung nilai $\mathrm{Q}=\frac{c}{c \text { maks }}$ $=\frac{0,390}{0,816}=0,477$ artinya terdapat asosiasi yan cukup antara kemampuan berpikir kreatif dengan koneksi matematik.

\section{Asosiasi Kemampuan Berpikir Kreatif dengan Motivasi Belajar siswa}

Untuk mengetahui ada tidaknya asosiasi antara kedua kemampuan tersebut dilakukan uji Chi-Square yang hasilnya disajikan dalam tabel 19 Berikut.

Tabel 19. Hasil uji Chi Square

\begin{tabular}{|l|r|r|r|}
\hline \multicolumn{4}{|c|}{ Chi-Square Tests } \\
\hline & \multicolumn{1}{|c|}{ Value } & Df & $\begin{array}{c}\text { Asymp. Sig. (2- } \\
\text { sided) }\end{array}$ \\
\hline Pearson Chi-Square & $9,706^{\mathrm{a}}$ & 4 &, 046 \\
\hline Likelihood Ratio & 10,716 & 4 &, 030 \\
Linear-by-Linear Association & 4,508 & 1 &, 034 \\
\hline N of Valid Cases & 35 & & \\
\hline
\end{tabular}

Pada tabel 19 hasil uji Chi- Square bahwa nilai sig adalah 0,046 karena nilai sig $0,046<0,05$ artinya terdapat asosiasi antara kemampuan berpikir kreatif dengan motivasi belajar siswa, selanjutnya dilakukan uji kontingensi $\mathrm{C}$ yang hasilnya disajikan dalam tabel 20 berikut. 


\section{Tabel 20. Hasil uji Kontingensi C}

\begin{tabular}{|c|c|c|c|c|c|}
\hline \multicolumn{6}{|c|}{ Symmetric Measures } \\
\hline & & Value & $\begin{array}{c}\text { Asymp. Std. } \\
\text { Error }^{\mathrm{a}}\end{array}$ & Approx. To & Approx. Sig. \\
\hline $\begin{array}{l}\text { Nominal by } \\
\text { Nominal }\end{array}$ & $\begin{array}{l}\text { Contingency } \\
\text { Coefficient }\end{array}$ & ,466 & & &, 046 \\
\hline \multirow[b]{2}{*}{ Ordinal by Ordinal } & Gamma & .508 & .219 & 2,089 & .037 \\
\hline & $\begin{array}{l}\text { Spearman } \\
\text { Correlation }\end{array}$ & ,364 & , 169 & 2,244 &, $032^{c}$ \\
\hline Interval by Interval & Pearson's R & .364 & .162 & 2,246 & $.032^{c}$ \\
\hline $\mathrm{N}$ of Valid Cases & & 35 & & & \\
\hline
\end{tabular}

Pada tabel 20 hasil uji Kontingensi C pada Value adalah 0,466, selanjutnya hitung nilai $\mathrm{Q}=\frac{c}{\text { cmaks }}=\frac{0,466}{0,816}=0,571$ artinya terdapat asosiasi yang cukup antara kemampuan berpikir kreatif dengan motivasi belajar.

\section{Asosiasi Kemampuan Koneksi Matematik dengan Motivasi Belajar siswa.}

Untuk melihat ada tidaknya asosiasi di lakukan uji Chi-Square yang hasilnya disajikan dalam tabel 21 berikut

Tabel 21. Hasil Uji Chi-Square

\begin{tabular}{|l|r|r|r|}
\hline & \multicolumn{4}{c}{ Chi-Square Tests } \\
\hline & Value & df & $\begin{array}{c}\text { Asymp. Sig. (2- } \\
\text { sided) }\end{array}$ \\
\hline Pearson Chi-Square & $6,290^{\mathrm{a}}$ & 2 & .043 \\
Likelihood Ratio & 6,980 & 2 &, 030 \\
Linear-by-Linear Association &, 260 & 1 & .610 \\
\hline N of Valid Cases & 35 & & \\
\hline
\end{tabular}

Pada tabel 21 hasil uji Chi- Square bahwa nilai sig adalah 0,043 karena nilai sig $0,043<0,05$ artinya terdapat asosiasi antara kemampuan berpikir kreatif dengan motivasi belajar siswa, selanjutnya akan dilakukan uji kontingensi $\mathrm{C}$ yang hasilnya disajikan dalam tabel 22 berikut.

Tabel 22. Hasil uji Kontingensi C

\begin{tabular}{|c|c|c|c|c|c|}
\hline & & Value & $\begin{array}{c}\text { Asymp. Std. } \\
\text { Error }^{3}\end{array}$ & Approx. To & Approx. Sig. \\
\hline $\begin{array}{l}\text { Nominal by } \\
\text { Nominal }\end{array}$ & $\begin{array}{l}\text { Contingency } \\
\text { Coefficient }\end{array}$ & ,390 & & &, 043 \\
\hline Ordinal by & Gamma & -.286 & 303 &,- 873 &, 382 \\
\hline Ordinal & Spearman Correlation &,- 150 &, 172 & -.874 &, $388^{\circ}$ \\
\hline $\begin{array}{l}\text { Interval by } \\
\text { Interval }\end{array}$ & Pearson's R &,- 087 &, 166 &,- 504 & $617^{\circ}$ \\
\hline \multicolumn{2}{|c|}{$\mathrm{N}$ of Valid Cases } & 35 & & & \\
\hline
\end{tabular}


Pada tabel 22 hasil uji Kontingensi C pada Value adalah 0,466, selanjutnya dihitung nilai $\mathrm{Q}=\frac{c}{c m a k s}=\frac{0,466}{0,816}=0,571$ artinya terdapat asosiasi yang cukup antara kemampuan koneksi matematik dengan motivasi belajar siswa.

\section{E. KESIMPULAN}

Berdasarkan hasil analisis temuan dan pembahasan yang telah diuraikan pada hasil dan pembahasan sebelumnya, dapat disimpulkan beberapa hal sebagai berikut:

1. Pencapaian kemampuan berpikir kreatif, koneksi matematik dan motivasi belajar siswa yang pembelajarannya dengan menggunakan pendekatan Metode Demontrasi lebih baik dari pada yang menggunakan pembelajaran biasa, dimana siswa yang pembelajarannya dengan menggunakan Metode Demontrasi berada pada level tinggi, sedangkan pada siswa dengan pembelajaran biasa berada pada level rendah.

2. Peningkatan kemampuan berpikir kreatif, koneksi matematika dan motivasi belajar siswa yang pembelajarannya dengan menggunakan pendekatan Metode Demontrasi, lebih baik daripada yang menggunakan pembelajaran biasa.

3. Terdapat asosiasi yang cukup antara kemampuan berpikir kreatif dengan kemampuan koneksi matematik.

4. Terdapat asosiasi yang cukup antara kemampuan berpikir kreatif dengan motivasi belajar siswa.

5. Terdapat asosiasi yang cukup antara kemampuan koneksi matematik dengan motivasi belajar siswa.

\section{REFERENSI}

Indrawan. ( 2016 ). Meningkatkan Kemampuan Komunikasi dan berpikir Kreatif Matematik Serta Self-Concept Siswa Sekolah Menengah Pertama Melalui Pembelajaran Berbasis Masalah. Tesis pada Program Magister Pendidikan Matematika. Bandung: Tidak diterbitkan.

Sabandar, J (2010). Berpikir Kreatif Makalah Prodi Pendidikan Matematika. SPS: UPI Bandung

Sardiman (2010). Interaksi dan Motivasi Belajar Mengajar. Jakarta: Rajawali Press.

Sumarmo, U. (2007). Mengembangkan kemampuan penalaran dan koneksi matematik siswa SMA melalui pembelajaran berbasis masalah. Bandung : universitas Pendidikan Indonesia. Dalam Jurnal Educationist: Jurnal Kajian Filosofi. Volume 1 No 2 